\title{
Induced systemic resistance -like responses elicited by rhizobia
}

\author{
María Laura Tonelli • María Soledad Figueredo • \\ Johan Rodríguez • Adriana Fabra • \\ Fernando Ibañez $(\mathbb{D}$
}

Received: 24 September 2019 / Accepted: 3 January 2020

(C) Springer Nature Switzerland AG 2020

\begin{abstract}
Background Rhizobia are soil bacteria that engage into a mutualistic symbiosis with plants and benefit the host by fixing atmospheric $\mathrm{N}$. In addition, rhizobia can be considered as biocontrol agents, contributing to plant health through direct inhibition of a wide range of pathogens. More recently, it became evident that rhizobial invasion of plant roots can also trigger an increased systemic resistance state in the host, a process resembling the Induced Systemic Resistance (ISR) mechanism. However, this indirect biocontrol property of rhizobia was relatively less explored.

Scope In this review article, we present an overview of the current knowledge of ISR -like responses induced by rhizobia, considering general characteristics of this phenomenon, discussing the molecular pathways leading to this response and highlighting potential links between ISR -like responses and the nodulation signaling pathway.

Conclusions A more detailed knowledge of these responses can result in development of biotechnological tools for sustainable crop production, through optimization of the systemic protective effect conferred by rhizobia.
\end{abstract}

Responsible Editor: Matthew G. Bakker.

M. L. Tonelli • M. S. Figueredo · J. Rodríguez · A. Fabra • F. Ibañez $(\bowtie)$

Instituto de Investigaciones Agrobiotecnológicas, CONICET, Universidad Nacional de Río Cuarto, 5800 Río Cuarto, Córdoba, Argentina

e-mail: fibanez@exa.unrc.edu.ar
Keywords Rhizobia $\cdot$ Legumes $\cdot$ Symbiosis $\cdot$ Defense Induced systemic resistance $\cdot$ Priming

\section{Rhizobia as biocontrol agents}

Rhizobia constitute a diverse group of microorganisms well known by their ability to induce formation of nitrogen fixing nodules in the roots or stems of legume plants. These bacteria exhibit two alternative lifestyles, one as free -living organisms inhabiting in soils and rhizosphere and other as plant endophytes. The ability to persist and succeed in both states relies on different strategies, each involving expression of specific traits.

As free -living bacteria in soils, rhizobia interact with a great microbial diversity, in fluctuating environmental conditions. As stable components of soil microbiota, rhizobia possess a plethora of metabolites and molecules that allow them to interact and compete with other soil microbes. In this sense, some rhizobial strains produce siderophores that chelate iron (Bejoysekar and Chakrabartty 2014; Gupta et al. 2018; Srinivasan 2017), antibiotics and hydrolytic enzymes active against diverse bacteria and fungus in the soils (Bhattacharya et al. 2013; Gopalakrishnan et al. 2015). Moreover, rhizobia use a wide variety of carbon sources, outcompeting other soil members (Gopalakrishnan et al. 2015). Since these properties can prevent the spread or activity of plant pathogens, rhizobia may be therefore considered as biocontrol agents. Indeed, it was demonstrated that rhizobia are able to prevent or reduce the incidence of several diseases in plants through 
expression of direct biocontrol properties (Arora et al. 2001; Das et al. 2017; Schmidt et al. 2018; Volpiano et al. 2018, 2019).

In the alternative endophytic lifestyle, rhizobia colonize plant tissues and engage into a very intimate association that benefits the legume host through Biological Nitrogen Fixation (BNF). To succeed in this alternative lifestyle, rhizobia should display a set of traits different to those expressed in soils. For instance, rhizobia must display particular features allowing evasion and temporal suppression of plant defense responses, in order to gain access to the interior of root tissues (Cao et al. 2017; Zamioudis and Pieterse 2012). Strikingly, rhizobial infection of the roots and symbiosis development can also lead to a plant increased systemic defense state, in a process resembling the Induced Systemic Resistance (ISR) mechanism well described for other Plant Growth Promoting Bacteria (PGPB) (Fernandez-Göbel et al. 2019; Pieterse et al. 2014; Yu et al. 2019). Molecular events mediating these responses are still not fully understood, and could involve a mechanism that differs from that described for other PGPB. Therefore, we propose the term ISR -like responses to describe the increased state of systemic defense elicited by rhizobia. In this article, we present an overview of ISR and discuss different aspects of the ISR -like responses induced by rhizobial bacteria.

\section{ISR responses in the context of plant immunity}

Plant defense responses

Plant roots are exposed to an enormous diversity of microbes, potentially capable of establishing a continuum spectrum of interactions ranging from mutualistic to pathogenic. Plant immune system exerts a key role, displaying gate -keeping functions that ward off pathogens but also promote and maintain beneficial microbes (Yu et al. 2019). Plant innate immunity towards pathogens is activated after recognition of microbe molecular patterns and effector molecules (Jones and Dangl 2006; Pieterse et al. 2012). Plant pattern -recognition receptors (PRRs) perceive common microbial compounds known as microbe -associated molecular patterns (MAMPs) such as flagellin, elongation factor Tu (EFTu), bacterial lipopolysaccharides and peptidoglycans, and fungal chitooligosaccharides (Saijo et al. 2018). PRRs represent the first defense line in plants and elicit a MAMP - triggered immunity (MTI), which is often efficient in controlling potential intruders. However, successful pathogens suppress MTI through virulence effector molecules, bypassing this first defense response. In turn, plant immune system has evolved a second line of defense called effector -triggered immunity (ETI), in which NB -LRR (nucleotide -binding-leucine rich repeat) receptor proteins recognize these effector molecules. ETI constitutes an accelerated and amplified MTI defense reaction and, usually, results in a hypersensitive cell death response (HR) at the infection site, which prevents invading pathogens (mainly biotrophs) to gain access to inner plant tissues. The local onset of MTI and ETI often results in an induced resistance in distant plant tissues. This phenomenon is known as systemic acquired resistance (SAR) and is characterized by local and systemic increased levels of salicylic acid (SA). However, SA itself does not make up the systemic signal. Instead, several plant metabolites have been proposed as putative long - distance signaling molecules, including the methyl ester of SA, azelaic acid and pipecolic acid, among others. This signaling event results in the systemic expression of pathogenesis -related (PR) genes, many of which encode PR proteins with antimicrobial activity (Pieterse et al. 2014).

The plant immune system plays a central role in the social network of plants. As stated above, it can be activated to ward off pathogens, but it must be suppressed in order to accommodate mutualists. It is generally accepted that beneficial endophytic microbes must overcome or evade plant immune local responses, mainly MTI, to achieve a successful root establishment and to exert their positive effect (Yu et al. 2019). In addition, an active plant -driven immune suppression has been shown to be required for rhizobia -legume symbiosis (Benezech et al. 2019). In order to better understand the significance, mechanisms involved and consequences of manipulating plant immunity, this trait should be considered in a wider scenario, as the result of a long evolutionary process including the acquisition and later refinement of a common molecular language (Bulgarelli et al. 2013; Oldroyd 2013) and appropriate plant -microbe responses (Lagunas et al. 2015).

ISR and priming in plants

ISR is a biocontrol mechanism by which selected microorganisms prime the whole plant body for an enhanced defense against a broad range of pathogens, 
without directly activating costly defenses (Pieterse et al. 2014). Root -associated biocontrol microorganisms, such as Pseudomonas, Bacillus, Trichoderma and mycorrhizal fungal species have been reported to induce systemic resistance in plants (Cameron et al. 2013; Choudhary and Johri 2009; De Vleesschauwer and Höfte 2009; Iavicoli et al. 2003; Kloepper et al. 2004; Van Loon et al. 1998). These beneficial microorganisms produce elicitors responsible for the onset of immunity, including antibiotics, flagella, $N$-acyl homoserine lactones, iron regulated siderophores, biosurfactants and volatile organic compounds, among others. Moreover, elicitors can act redundantly to elicit MTI (Ongena et al. 2007; Pieterse et al. 2014; Stringlis et al. 2018).

Once the specific elicitor is locally perceived, a signaling pathway is triggered in order to accurately respond to this molecule. After these local responses are switched on, a second immune signaling event allows transforming the local phenomenon into a potentiated systemic state of defense (Fig. 1a, b). Like in SAR, a long distance signaling molecule (not identified yet) activates the systemic immunity in distant plant tissues. However, unlike SAR, ISR expressing plants do not accumulate PR proteins after the initial stimulus, and JA - or ET - dependent defense genes (and in some cases SA -dependent genes) are expressed only after pathogen attack (second stimulus) (Pieterse et al. 2014). A large number of studies supports that ISR triggered by beneficial microbes is based on an enhanced defense response as a consequence of a stronger and/or faster defense reaction when the plant is exposed to biotic or abiotic stress (Conrath et al. 2006, 2015; Figueredo et al. 2014; Tonelli et al. 2011). This phenomenon, called priming, is defined as the physiological state (the primed state of defense) in which the plant is conditioned for the superactivation of defenses against environmental challenges (Martinez-Medina et al. 2016). Since defense responses are only deployed following the perception of the triggering stimulus, priming is proposed to be an adaptive, low -cost defensive mechanism (Mauch-Mani et al. 2017).

Priming is characterized by the acquisition of memory with a low fitness cost, more robust defense response, and better performance in challenged plants. Priming can be maintained throughout the plant's life cycle and can be even transmitted to subsequent generations, therefore representing a type of immunological memory (Martinez-Medina et al. 2016; Mauch-Mani et al. 2017).

Modulation of legume immunity by rhizobia

It is generally assumed that rhizobia are first recognized by plants as intruders, and that hosts mount a defense response against these bacteria. Development of a successful interaction will depend on the bacterial ability to evade, block or overcome plant defenses (Soto et al. 2006, 2009; Zamioudis and Pieterse 2012). Similarities in the molecular signals, machinery and mechanisms used by rhizobia and pathogens to invade plants support the notion that nitrogen fixing symbiosis has evolved from pathogenic interactions (Deakin and Broughton 2009). Therefore, it becomes evident that modulation of plant immunity plays an important role in symbiosis development. Some particular structural features of rhizobial cells are related with evading MTI. For instance, rhizobial bacteria do not possess the flg22 epitope (a well characterized MAMP) (Felix et al. 1999; LopezGomez et al. 2011). In addition, legume hosts lack the ability to mount a defense response to other potential MAMPs such as the elf1 8 peptide of EFTu and the csp15 peptide from rhizobial cold shock proteins (Boller 2005).

Besides avoiding recognition by plants, classical view of symbiosis development indicates that a successful interaction also relies on the rhizobial ability to actively suppress the host innate immunity. Early transcriptomic experiments performed in model legumes seemed to support this notion, revealing a transient induction of defense genes at the first steps of the interaction that is later repressed (Clúa et al. 2018; Kouchi et al. 2004; Libault et al. 2010; Lohar et al. 2006). However, recent works performed in Lotus and Aeschynomene challenge this classical view, raising questions about the existence of this transient defense induction (Gully et al. 2018; Kelly et al. 2018; Benezech et al. 2019). Nevertheless, it is clear that plant immunity has to be regulated during symbiosis development. This regulation is achieved through both plant and bacterial factors. Several rhizobial molecules have been related with the suppression of the defense responses, including Nod factors (NFs), effectors secreted through Type III secretion system (T3SS) and surface polysaccharides such as extracellular polysaccharides (EPS), lipopolysaccharides (LPS), capsular polysaccharides (KPS) and cyclic $\beta$-glucans (Janczarek et al. 2015). 


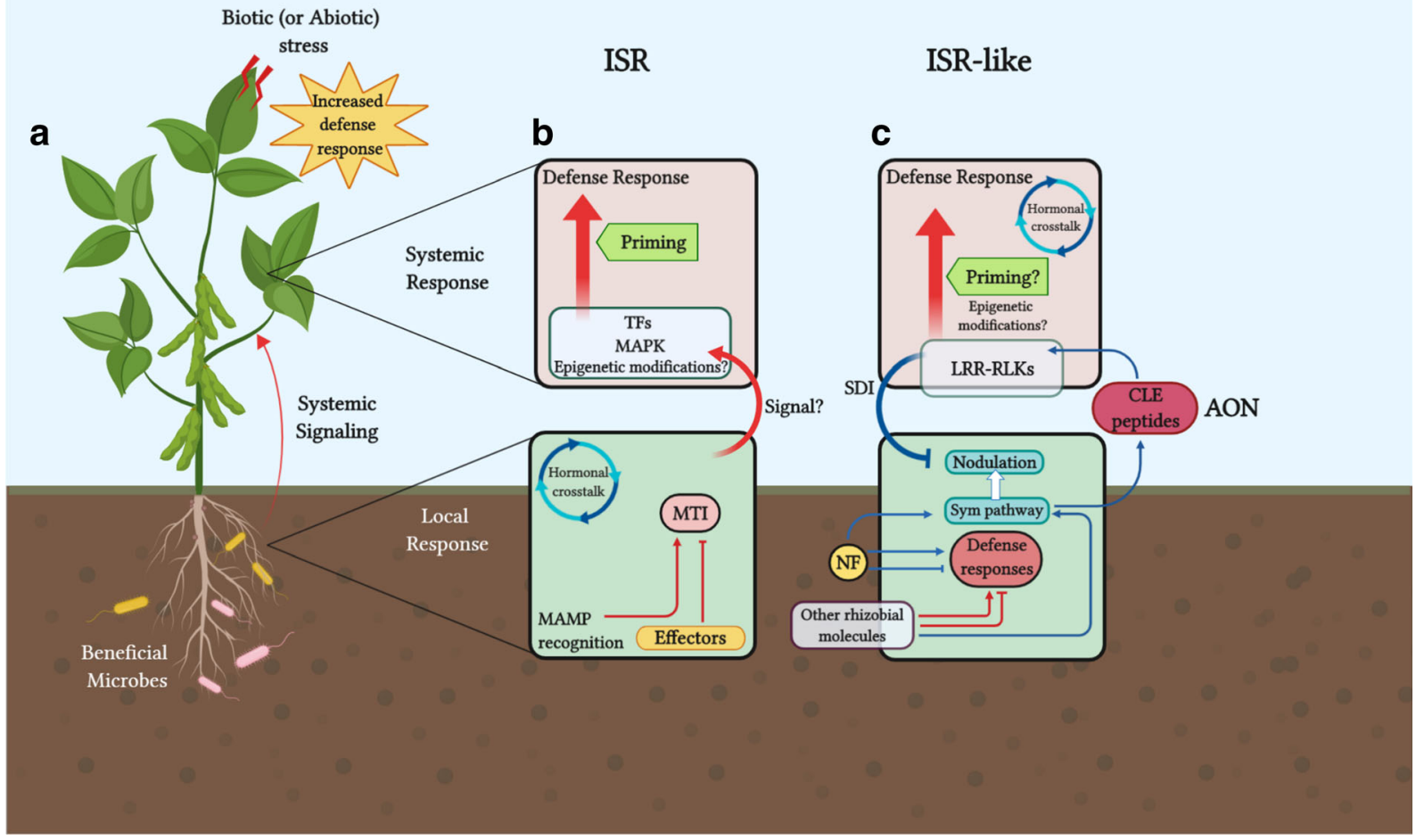

Fig. 1 Systemic defense responses induced by rhizobial and nonrhizobial beneficial microbes. a A local stimulus induced by beneficial microorganisms (in this case, in the plant roots) triggers an increased systemic defense response in the host. This increased response is expressed after biotic or abiotic stress challenge. Local and systemic responses are connected through a systemic signal. b Induced systemic resistance elicited by non-rhizobial PGPR. A local stimulus (MAMP perception) triggers MTI, which can be later attenuated by microbial effectors. MTI often results in an increased systemic defense response. A hormonal crosstalk is involved in sensing and connecting local and systemic defense responses. However, the precise nature of the signal linking local and systemic responses has not been determined yet. Perception of the systemic signal results in transcriptional reprogramming of transcription factors (TFs) and mitogen-activated protein kinases (MAPKs), leading to a primed state of defense. Epigenetic modifications may also be related with this primed defense. After a challenge, the plant defense response is faster and more robust

\section{Nod factors}

NFs are key molecules involved in legume -rhizobia symbiosis. They consist of an $\mathrm{N}$-acetyl glucosamine backbone with an $\mathrm{N}$-linked fatty acid moiety and several species specific molecular decorations. NFs are produced by rhizobia in response to (iso)flavonoids secreted by their compatible hosts, at the onset of the molecular recognition between legumes and rhizobia. than in non-induced plants. c ISR-like responses induced by rhizobia. Nodulating bacteria produce signaling molecules (NF). NF perception by LysM-RLKs triggers a sym pathway that initiates the epidermal and cortical responses required for nodulation process. In addition, NFs and other rhizobial molecules such as effectors secreted through T3SS modulate plant defense reactions, inducing features related with immune signaling and/or decreasing this response. In the absence of NF, sym pathway can also be activated by T3SS effectors in some associations. Nodulation process is regulated by the autoregulation of nodulation (AON) system. During this phenomenon, CLE peptides are produced in the roots and migrate to the shoot where they are recognized by a LRR-RLK. A shoot derived inhibitory signal (SDI) travels to the root, preventing over nodulation. AON system can be related with the systemic increase in the defense response (ISR-like responses induced by rhizobia), probably mediated by a primed state involving a hormonal crosstalk and epigenetic modifications

Even when it is not a general rule, these signaling molecules are essential for the initiation of symbiosis in the majority of the studied associations. NFs perception by specific LysM -RLKs (Lysin -motif Receptor Like Kinases) triggers a signaling transduction pathway that allows bacterial infection and nodule organogenesis in legumes, processes tightly coordinated. In addition, a role for NF perception in suppressing plant MTI responses has been proposed (Cao et al. 2017; Muñoz 
et al. 2015), possibly by reducing the levels of PRRs on the plasma membrane (Cao et al. 2017). Interestingly, NFs effect over plant MTI responses is not restricted to legumes, since it was also observed in A. thaliana, tomato and corn (Liang et al. 2013). In a recent work, Rey et al. (2019) reported that pre -incubation of Medicago seedlings with NFs inhibited the ROS burst generated by inoculation of a culture filtrate of Aphanomyces euteiches. However, ROS inhibition did not affect induction of defense genes or the overall plant pathogen resistance (Rey et al. 2019).

Molecular mechanisms by which NFs interfere with the host's immune system are not well understood, but it seems clear that activation of the Nod signaling pathway suppresses SA-dependent defense responses (MartinezAbarca et al. 1998; Zamioudis and Pieterse 2012). Striking similarities between defense modulation by rhizobia and biotrophic pathogens suggest that nodulating bacteria can be regarded as biotrophic mutualists (Gutjahr and Paszkowski 2009).

On the other hand, it has been also demonstrated that NFs themselves can induce some responses classically associated with plant immune signaling (Day et al. 2001; D'Haeze and Holsters 2002).

\section{Type III secretion system}

Other rhizobial molecules related with suppression of plant defenses are the effectors secreted through type III secretion system (T3SS). T3SS is a complex secretory system that allows injecting proteins (called effectors) into the host cell cytoplasm. Even when the role of the T3SS in mutualistic plant -microbe interactions is unclear, it is known that in the Rhizobium -legume symbiosis certain microbial effectors suppress defense reactions while others possess avirulence activities (Zamioudis and Pieterse 2012). As a consequence, T3SS effectors may function as host -range specificity determinants (Yang et al. 2010).

Interestingly, protein secreted through T3SS display dissimilar roles in different legume hosts. In this sense, mutation of T3SS in a bradyrhizobial strain able to nodulate legumes belonging to Dalbergioid, Millettioid, and Genistoid tribes resulted in contrasting symbiotic phenotypes when inoculated in the different host plants (Songwattana et al. 2017). Moreover, the same T3SS effector can play different roles even in phylogenetically related legume species. InnB effector secreted by Bradyrhizobium elkanii USDA61 into host cells plays a negative role in Vigna radiata, probably by triggering ETI and aborting symbiosis development. However, this effector plays a beneficial role in rhizobial symbiosis with the phylogenetically related host plant Vigna mungo (Nguyen et al. 2018).

In addition, T3SS effectors can also trigger nodulation signaling pathway during rhizobia -legume symbiosis. It was demonstrated that T3SS is crucial to promote nodulation of Glycine max and Aeschynomene indica in a NF independent manner (Okazaki et al. 2013, 2016). These data suggest that further studies are required in order to draw a better picture of the important role of rhizobial T3SS effectors in legume nodulation.

Cell surface polysaccharides

Interaction between rhizobial strains and their host legumes involves bacterial cell surface polysaccharides. These molecules participate in cell -to -cell interactions, biofilm formation and root colonization, and play important roles during the early events leading to the establishment of symbiosis (Donlan 2002). In addition, cell surface polysaccharides such as lipopolysaccharides (LPS), extracellular polysaccharides (EPS), capsular polysaccharides (KPS) and cyclic $\beta$-glucans (CG) can help rhizobia to tolerate the plant defense response or mediate its attenuation in host legumes (Tellström et al. 2007).

\section{Lipopolysaccharides (LPS)}

LPS are components of cell wall in Gram negative bacteria, including rhizobia. LPS from rhizobial cells have the same general structural architecture as those from Gram -negative pathogens. They consist of lipid A, $\mathrm{O}$-antigen and a core oligosaccharide. It is interesting to note that rhizobia produce a lipid A with unique structural characteristics such as the absence of one or both of the 1 - and 4 -phosphate groups at the $\beta-(1,6)$ - glucosamine disaccharide (De Castro et al. 2008) and the presence of very long chain fatty acids (VLCFA) (Brown et al. 2011; Ramadas Bhat et al. 1994), also observed in several bacteria that establish persistent intracellular infection in their hosts. VLCFA have been related with cell -envelope stability and stress adaptation of rhizobia both in planta and in free -living conditions (Bourassa et al. 2017). 
Early works showed that LPS are essential for symbiosis development, and that structural modifications in the $\mathrm{O}$-antigen and lipid A regions occur during this interaction (D'Haeze et al. 2007; Kannenberg and Carlson 2001; Kannenberg et al. 1998). Rhizobial mutants in LPS are not only symbiotically defective but also induce an increased defense response. Therefore, it is assumed that rhizobial LPS are involved in defense response attenuation of host legumes (Tellström et al. 2007).

\section{Exopolysaccharides (EPS)}

Exopolysaccharides produced by rhizobia are chemically diverse heteropolymers composed by linear or branched repeating units containing monosaccharides (D -glucuronic or D -galacturonic acid, D -glucose, D galactose, D -mannose, L -rhamnose) usually substituted with non -carbohydrate moieties. An active role of EPS in signaling to ameliorate plant defense responses has been proposed. Recognition of rhizobial EPS by legumes is crucial for infection, and a bacterial EPS receptor 3 (Epr3) has been identified in L. japonicus (Kawaharada et al. 2015). Several studies reported that callose deposition and antimicrobial compounds production are suppressed by EPS (Albus et al. 2001; Scheidle et al. 2005). In addition, EPS are necessary for negative regulation of genes related with plant defense responses and calcium chelation (Aslam et al. 2008; Jones et al. 2008; Tellström et al. 2007). However, the precise function of rhizobial EPS during infection remains unresolved.

\section{Capsular polysaccharides (KPS)}

Rhizobial KPS are strain -specific antigens tightly associated with the outer membrane (Fraysse et al. 2005; Haeze et al. 2004; Kannenberg et al. 1998; Pellock et al. 2000). They are acidic linear polysaccharides, usually comprising disaccharide repeating units (Le Quere et al. 2006; Reuhs et al. 1993, 1995). KPS probably functions as a signal molecule during the early stages of symbiosis, and can also confer protection to rhizobia against plant defense (Janczarek et al. 2015).

Cyclic $\beta$-glucans (CG)

Cyclic $\beta$-glucans (CG) are sugar oligomers secreted by rhizobia into the periplasmic space. These sugar oligomers consist of D -glucose units that may be substituted with non -glycosidic anionic groups (Lepek and D'Antuono 2005; Schue et al. 2011). Considering that $\mathrm{CG}$ can protect rhizobia against detergents, it can be hypothesized, as for others surface polysaccharides, that they may also protect rhizobia against plant defense responses.

It is important to consider that, even when the different microbial molecules were presented separately in this article, they are almost simultaneously perceived by plants as a whole. This singular combination constitutes a bacterial hallmark, allowing host recognition according to the microbe lifestyle (pathogen, symbiont, non -symbiotic beneficial microbe, etc). Therefore, the outcome of plant responses after microbial perception represents the balance of multiple interconnected signaling pathways acting simultaneously, and not the response to a single bacterial molecule.

Finally, it is important to consider recent works describing an active plant -driven suppression of immunity during rhizobia legume -interaction. This response prevents defense reactions, allowing a massive colonization of plant organs and bacteroid persistence within the nodules. Several proteins implicated in this response were identified in model legumes, and include RSD1, SymCRK, DNF2 and NAD1 in Medicago (Berrabah et al. 2014; Bourcy et al. 2013; Domonkos et al. 2017; Sinharoy et al. 2013) and APN1 in Lotus (Yamaya-Ito et al. 2018).

\section{ISR -like responses displayed by rhizobia}

Many works provide data supporting the notion that inoculation of legumes with rhizobia results in the induction of an increased defense response effective against diverse pathogens (necrotrophs, biotrophs) and herbivores (Arfaoui et al. 2005, 2006, 2007; Chakraborty and Chakraborty 1989; Diaz-Valle et al. 2019; Dutta et al. 2008; Figueredo et al. 2014, 2017; Kalantari et al. 2018; Mabrouk et al. 2007; Osdaghi et al. 2011; Rabie 1998; Smigielski et al. 2019) (Table 1). This effect was also observed in non legumes after rhizobial inoculation (Mishra et al. 2006; Reitz et al. 2000). Moreover, this defense response is usually referred as systemic. However, confirming systemic nature of a defense response induced by rhizobial inoculation depends on carefully designed experiments, involving (at least) three components: plants, rhizobia and 
pathogens. In addition, inoculation of rhizobia and pathogen must be spatially separated to avoid the possibility of a direct inhibition between these microbes. In the case of pathogens affecting the aerial part of plants, spatial separation with rhizobia is natural. However, for soilborne pathogens, systems like split -root or overlapping pots were used. Furthermore, to confirm that the defense response is systemic, the protective effect must be determined in organs different to those inoculated with rhizobia. These conditions are fulfilled in some of the works, confirming that rhizobia induce a defense response resembling ISR (Diaz-Valle et al. 2019; Dutta et al. 2008; Figueredo et al. 2014, 2017, 2018). However, many others works were not originally designed with this aim and, therefore, fail to accomplish some of the requirements. Besides, it is important to consider that plant nutritive status will affect the plant fitness and, therefore, its response towards pathogen challenge. This is especially important considering that rhizobia contribute to plant nutrition through nitrogen -fixation. This fact adds another layer of complexity when it comes to interpret the results. Nevertheless, there are a number of observations consistent with the notion that rhizobial inoculation induces defense responses resembling the ISR process well described for others PGPB.

Local responses induced by rhizobia leading to systemic resistance

Symbiotic plant -beneficial microbe interactions require a high degree of coordination and a complex molecular dialogue between both partners (Cameron et al. 2013; Van Wees et al. 2008; Zamioudis and Pieterse 2012). As stated before, it is now generally assumed that rhizobia actively suppress the host immune response to allow infection and symbiosis. Therefore, it has been proposed that local responses related with the immune suppression lead to a systemic state of resistance (Beardon et al. 2014). The nature of the rhizobial molecules triggering the systemic signaling is not clear yet. Considering that NFs possess a dual role over plant defense (suppressing and activating features related with innate immunity), they may be related with the priming of systemic responses in the host. Some evidences support this hypothesis. Rey et al. (2013) reported that Medicago truncatula mutants unable to perceive Nod factors were more susceptible to A. euteiches and Colletotrichum trifolii than wild -type plants, suggesting a crosstalk between NF receptors and defense responses. In addition, peanut plants inoculated with a bradyrhizobial strain defective in NF production display higher incidence and severity of the stem rot caused by Sclerotium rolfsii than plants inoculated with the ISR -eliciting wild -type strain (Figueredo et al. 2017). Recently, a rapid systemic redox change after inoculation of soybean roots with Bradyrhizobium japonicum was demonstrated (Fernandez-Göbel et al. 2019). Furthermore, the authors showed that this systemic response (related to an increased resistance against abiotic stress) is NF -dependent. However, how these local responses elicited by NFs result in a systemic effect, and which is the molecular pathway related to this mechanism, are not known.

Based on current knowledge, some hypotheses have been proposed, suggesting a role for phytohormones, small RNAs and autoregulation of nodulation (AON) system as long distance signals of local responses (Beardon et al. 2014). Rhizobia have evolved mechanisms to efficiently control SA levels of host plants and establish successful infections. This suppression of SA dependent defenses can balance the host immunity towards JA -related defenses, mostly active against herbivorous and necrotrophic pathogens. However, the role of JA as long distance signal of ISR and the importance of SA and JA -mediated signaling in rhizobium -legume symbiosis have not been demonstrated (Beardon et al. 2014; Gutjahr and Paszkowski 2009). Interestingly, priming for SA accumulation and SA -mediated defense active against the powdery mildew fungi (biotroph) was observed in Medicago plants after rhizobial inoculation (Smigielski et al. 2019). Moreover, even when suppression of SA -dependent defense responses seems to be widespread in rhizobial symbiosis, transcriptomic data indicates that peanut increase SA response during symbiosis development. This leads to the expression of a group of divergent PR - 1 that is probably required for symbiosis (Karmakar et al. 2019). Differences in the modulation of the plant immune system can be related with the more primitive infection mechanism described for this legume.

Other molecules proposed as systemic signals are small RNAs (sRNAs), a population of 21 to 24 nucleotide RNAs molecules that mediate RNA silencing. These molecules are able to move by phloem, acting as gene repressors at transcriptional and post -transcriptional level (Bonnet et al. 2006; Katiyar-Agarwal and Jin 2010; Liu and Chen 2018). However, further investigations are necessary 
Table 1 ISR-like responses induced by rhizobial inoculation on legumes

\begin{tabular}{|c|c|c|c|c|c|c|}
\hline $\begin{array}{l}\text { Legume } \\
\text { host }\end{array}$ & $\begin{array}{l}\text { Rhizobial } \\
\text { strain }\end{array}$ & Pathogen & Effects & $\begin{array}{l}\text { Spatial } \\
\text { separation } \\
\text { between } \\
\text { rhizobia } \\
\text { and } \\
\text { pathogen }\end{array}$ & Additional comments & Reference \\
\hline $\begin{array}{l}\text { Pisum } \\
\quad \text { sativum } \\
\quad \text { L. }\end{array}$ & $\begin{array}{l}\text { Rhizobium } \\
\text { leguminosar- } \\
\text { um }\end{array}$ & $\begin{array}{l}\text { Fusarium } \\
\quad \text { solani f. sp. } \\
\text { pisi }\end{array}$ & $\begin{array}{l}\text {-Rot index per plant was } \\
\text { diminished. } \\
\text {-Phytoalexin production was } \\
\text { increased. }\end{array}$ & No & $\begin{array}{l}\text {-In vitro tests with } \\
\text { F. solani f. sp. pisi and } \\
\text { R. leguminosarum } \\
\text { showed no direct } \\
\text { antagonistic effects on } \\
\text { solid medium. }\end{array}$ & $\begin{array}{l}\text { Chakraborty } \\
\text { and } \\
\text { Chakrabo- } \\
\text { rty } 1989 .\end{array}$ \\
\hline Vicia faba & $\begin{array}{l}\text { Rhizobium } \\
\text { leguminosar- } \\
\text { um }\end{array}$ & Botrytis fabae & $\begin{array}{l}\text {-Percentage of infection was } \\
\text { reduced. } \\
\text {-Phenolic compounds content } \\
\text { was increased. }\end{array}$ & No & & Rabie 1998. \\
\hline $\begin{array}{l}\text { Cicer } \\
\quad \text { arietin- } \\
\text { um L. }\end{array}$ & Rhizobium sp. & $\begin{array}{l}\text { Fusarium } \\
\quad \text { oxysporum } \\
\quad \text { f. sp. ciceris }\end{array}$ & $\begin{array}{l}\text {-Wilt incidence was reduced. } \\
\text {-Peroxidase and polyphenol } \\
\text { oxidase activity, expression of } \\
\text { phenylalanine } \\
\text { ammonia-lyase, chalcone } \\
\text { synthase and isoflavone } \\
\text { reductase genes, and } \\
\text { accumulation of phenolic } \\
\text { compounds were increased. }\end{array}$ & No & $\begin{array}{l}\text {-In vitro tests with } \\
\text { F. oxysporum f. sp. } \\
\text { ciceris and Rhizobium } \\
\text { sp. showed direct } \\
\text { antagonistic effects on } \\
\text { solid medium. }\end{array}$ & $\begin{array}{l}\text { Arfaoui et al } \\
2005 \\
2006 \\
2007\end{array}$ \\
\hline $\begin{array}{l}\text { Pisum } \\
\quad \text { sativum } \\
\quad \mathrm{L} .\end{array}$ & $\begin{array}{l}\text { Rhizobium } \\
\text { leguminosar- } \\
\text { um }\end{array}$ & $\begin{array}{l}\text { Orobanche } \\
\text { crenata }\end{array}$ & $\begin{array}{l}\text {-Root infection by } \\
O \text {. crenata was reduced. } \\
\text {-Peroxidase and phenylalanine } \\
\text { ammonia lyase activity were } \\
\text { increased. }\end{array}$ & No & & $\begin{array}{l}\text { Mabrouk } \\
\text { et al. } \\
2007 .\end{array}$ \\
\hline $\begin{array}{l}\text { Cajanus } \\
\quad \text { cajan } L .\end{array}$ & Rhizobium sp. & $\begin{array}{l}\text { Fusarium } \\
\text { udum }\end{array}$ & $\begin{array}{l}\text {-Appearance of wilting } \\
\text { symptoms was delayed. } \\
\text {-Severity of disease was reduced. } \\
\text {-Peroxidase, phenylalanine } \\
\text { ammonia lyase and } \\
\text { polyphenol oxidase activity } \\
\text { was induced, and phenolic } \\
\text { compounds content was } \\
\text { increased. }\end{array}$ & Yes & $\begin{array}{l}\text {-Production of lytic } \\
\text { enzymes and fusaric } \\
\text { acid by the pathogen } \\
\text { were not affected by } \\
\text { Rhizobium sp. }\end{array}$ & $\begin{array}{l}\text { Dutta et al. } \\
2008 \text {. }\end{array}$ \\
\hline $\begin{array}{l}\text { Phaseolus } \\
\text { vulgaris }\end{array}$ & $\begin{array}{l}\text { Rhizobium } \\
\text { leguminosar- } \\
\text { um }\end{array}$ & $\begin{array}{l}\text { Xanthomonas } \\
\text { axonopodis } \\
\text { pv. } \\
\text { Phaseoli }\end{array}$ & $\begin{array}{l}\text {-Common bacterial blight was } \\
\text { suppressed. }\end{array}$ & No & & $\begin{array}{l}\text { Osdaghi } \\
\text { et al. } \\
2011\end{array}$ \\
\hline $\begin{array}{l}\text { Arachis } \\
\quad \text { hypoga- } \\
\quad \text { ea L. }\end{array}$ & $\begin{array}{l}\text { Bradyrhizobium } \\
\text { sp. }\end{array}$ & $\begin{array}{l}\text { Sclerotium } \\
\quad \text { rolfsii }\end{array}$ & $\begin{array}{l}\text {-Wilting incidence and severity } \\
\text { were diminished. } \\
\text {-Phenolic compounds content } \\
\text { was increased. }\end{array}$ & Yes & $\begin{array}{l}\text {-Bradyrhizobium sp. Nod } \\
\text { factors participate in the } \\
\text { systemic resistance } \\
\text { against } S \text {. rolfsii. }\end{array}$ & $\begin{array}{l}\text { Figueredo } \\
\text { et al. } \\
\text { (2014, } \\
2017 \text {, } \\
\text { 2018). }\end{array}$ \\
\hline $\begin{array}{l}\text { Phaseolus } \\
\text { vulgaris }\end{array}$ & $\begin{array}{l}\text { Rhizobium } \\
\text { leguminosar- } \\
\text { um }\end{array}$ & $\begin{array}{l}\text { Fusarium } \\
\quad \text { solanif. sp. } \\
\quad \text { phaseoli }\end{array}$ & $\begin{array}{l}\text {-R. leguminosarum suppressed } \\
\text { Fusarium root rot and } \\
\text { increased plant and root } \\
\text { weight. }\end{array}$ & No & & $\begin{array}{l}\text { Kalantari } \\
\text { et al. } \\
\quad(2018) \text {. }\end{array}$ \\
\hline
\end{tabular}


Table 1 (continued)

\begin{tabular}{|c|c|c|c|c|c|c|}
\hline $\begin{array}{l}\text { Legume } \\
\text { host }\end{array}$ & $\begin{array}{l}\text { Rhizobial } \\
\text { strain }\end{array}$ & Pathogen & Effects & $\begin{array}{l}\text { Spatial } \\
\text { separation } \\
\text { between } \\
\text { rhizobia } \\
\text { and } \\
\text { pathogen }\end{array}$ & Additional comments & Reference \\
\hline $\begin{array}{l}\text { Medicago } \\
\quad \text { truncat- } \\
\quad \text { ula }\end{array}$ & $\begin{array}{l}\text { Sinorhizobium } \\
\text { meliloti }\end{array}$ & Erysiphe pisi & $\begin{array}{l}\text {-Less penetration of the fungus } \\
\text { was observed. }\end{array}$ & No & $\begin{array}{l}\text {-Elevated levels of free SA } \\
\text { and SA-dependent } \\
\text { marker gene expression }\end{array}$ & $\begin{array}{l}\text { Smigielski } \\
\text { et al. } \\
\text { (2019). }\end{array}$ \\
\hline $\begin{array}{l}\text { Pisum } \\
\quad \text { sativum }\end{array}$ & $\begin{array}{l}\text { Rhizobium } \\
\text { leguminosar- } \\
\text { um }\end{array}$ & & $\begin{array}{l}\text {-Asexual spore formation was } \\
\text { reduced. }\end{array}$ & No & $\begin{array}{l}\text { upon pathogen infec- } \\
\text { tion. }\end{array}$ & \\
\hline $\begin{array}{l}\text { Phaseolus } \\
\text { vulgaris }\end{array}$ & Rhizobium etli & $\begin{array}{l}\text { Pseudomonas } \\
\text { syringae pv. } \\
\text { phaseolico- } \\
\text { la }\end{array}$ & $\begin{array}{l}\text {-Disease symptomatology and } \\
\text { pathogen colonization were } \\
\text { diminished. } \\
\text {-Accumulation of the superoxide } \\
\text { anion }\left(\mathrm{O} 2^{-}\right) \text {and a faster and } \\
\text { stronger callose deposition } \\
\text { were observed. }\end{array}$ & Yes & $\begin{array}{l}\text {-Expression of defense } \\
\text { related genes in plants } \\
\text { treated with } R . \text { etli } \\
\text { exhibited a pattern that } \\
\text { is typical of the priming } \\
\text { response. } \\
\text {-Plants treated with } R \text {. etli } \\
\text { developed a } \\
\text { transgenerational } \\
\text { defense memory. }\end{array}$ & $\begin{array}{l}\text { Diaz-Valle } \\
\text { et al. } \\
\text { (2019). }\end{array}$ \\
\hline
\end{tabular}

to provide insight into the role of sRNAs as long distance ISR regulators.

An alternative explanation that accounts for the systemic protection conferred by root nodule symbiosis is to consider it as a part of a more widespread autoregulatory mechanism that limits the root colonization by all type of mutualists (Zamioudis and Pieterse 2012). Biotrophic symbionts such as rhizobia consume considerable amounts of carbohydrates. Therefore, the host retained mechanisms to control the number of nodules so as to balance the benefits/costs of mutualism (Gutjahr and Paszkowski 2009). The autoregulation of this symbiotic association is initiated in the roots, where rhizobial infection triggers the production of CLE glycopeptides that move via xylem to the shoot. There, they are perceived by a homo - or heterodimeric receptor complex (Ferguson et al. 2019). After perception, a second unknown signal (possibly cytokinins or a micro RNA) is generated in the shoot and is translocated back to the roots via the phloem to restrict nodule formation and root susceptibility to rhizobial infection (Miri et al. 2019; Tsikou et al. 2018). This phenomenon is known as AON. Interestingly, legume plants mutated in the CLE peptide receptor are hyper susceptible to nematode (Lohar and Bird 2003) and pathogen (Tazawa et al. 2007) infection and abiotic stress (Fernandez-Göbel et al. 2019), suggesting that systemic defense signaling may be an intrinsic part of the autoregulation phenomenon (Fig. 1c). The AON phenomenon, at least superficially, resembles ISR, since a microbial infection in local tissues primes resistance against secondary infections in distant plant parts. Therefore, it has also been proposed that ISR -like responses induced by rhizobia could be the result of a more general mechanism of autoregulation of microorganism -plant mutualistic interaction, providing systemic protection in roots and shoots against a broad spectrum of pathogens (Zamioudis and Pieterse 2012).

\section{Concluding remarks and future perspectives}

Rhizobia are soil bacteria that establish a symbiotic nitrogen fixation association with legumes, improving the nutritional state and fitness of the host plant. Experimental evidences support the notion that an additional benefit of rhizobial inoculation is related with a systemic increase of plant defense responses. However, some questions regarding the evolutionary origin and significance of this trait are still open. For instance, is ISR -like response elicited by rhizobia an evolutionary remnant of their pathogenic origins? In this sense, is it a side effect 
of the host innate immunity manipulation? Or is it a requisite for symbiosis success, related with a more general phenomenon involving self -regulation of all types of mutualism?

ISR -like responses elicited by rhizobia on legumes constitute an interesting research field. However, lack of experiments specifically designed with the aim of understanding this response has hindered the possibility to gain further insight into the molecular base implicated in this phenomenon. Therefore, a shift in the approaches used to study rhizobial ISR -like responses is essential. This research (together with a meta -analysis of available data), will provide valuable information in order to unravel the molecular signals and pathways involved in the local and systemic defense responses. Moreover, the effect of this ISR - like responses over the composition and structure of the host microbiome should not be missed. Results of these investigations will be relevant from a basic perspective, but could also impact on productive systems, by optimizing the protective effect conferred by rhizobia.

Acknowledgments The authors would like to thank anonymous reviewers, whose comments and suggestions helped to significantly improve and clarify this manuscript.

Funding information This study was financially supported by SECyT -UNRC, CONICET and ANPCyT. María Soledad Figueredo and Johan Rodríguez are recipients of scholarship from CONICET. María Laura Tonelli, Adriana Fabra and Fernando Ibáñez are members of the Research Career from CONICET.

\section{References}

Albus U, Baier R, Holst O, Pühler A, Niehaus K (2001) Suppression of an elicitor-induced oxidative burst reaction in Medicago sativa cell cultures by Sinorhizobium meliloti lipopolysaccharides. New Phytol 151:597-606

Arfaoui A, Sifi B, El Hassni M, El Hadrami I, Boudabbous A, Chérif M (2005) Biochemical analysis of chickpea protection against Fusarium wilt afforded by two Rhizobium isolates. Plant Pathol J 4:35-42

Arfaoui A, Sifi B, Boudabous A, Hadrami IE, Cherif M (2006) Identification of Rhizobium isolates possessing antagonistic activity against Fusarium oxysporum $\mathrm{f}$. sp. ciceris, the causal agent of Fusarium wilt of chickpea. J Plant Pathol 88:67-75

Arfaoui A, El Hadrami A, Mabrouk Y, Sifi B, Boudabous A, El Hadrami I, Chérif M (2007) Treatment of chickpea with Rhizobium isolates enhances the expression of phenylpropanoid defense-related genes in response to infection by Fusarium oxysporum f. sp. Ciceris. Plant Physiol Biochem 45:470-479
Arora NK, Kang SC, Maheshwari DK (2001) Isolation of siderophore-producing strains of Rhizobium meliloti and their biocontrol potential against Macrophomina phaseolina that causes charcoal rot of groundnut. Curr Sci 81:673-677

Aslam SN, Newman MA, Erbs G, Morrissey KL, Chinchilla D, Boller T, Jensen TT, De Castro C, Ierano T, Molinaro A, Jackson RW (2008) Bacterial polysaccharides suppress induced innate immunity by calcium chelation. Curr Biol 18 : $1078-1083$

Beardon E, Scholes J, Ton J (2014) How do beneficial microbes induce systemic resistance? In: Walters DR, Newton AC, Lyon GD (eds) Induced resistance for plant defense: a sustainable approach to crop protection, 2nd edn. UK, Wiley Blackwell, pp 232-248

Bejoysekar D, Chakrabartty PK (2014) Siderophore biosynthesis genes of Rhizobium sp. isolated from Cicer arietinum L. Botech 4:391-401

Benezech C, Doudement M, Gourion B (2019) Legumes tolerance to rhizobia is not always observed and not always deserved. Cell Microbiol

Berrabah F, Bourcy M, Eschstruth A, Cayrel A, Guefrachi I, Mergaer P, Wen J, Jean V, Mysore KS, Gourion B, Ratet P (2014) A nonRD receptor-like kinase prevents nodule early senescence and defense-like reactions during symbiosis. New Phytol 203:1305-1314

Bhattacharya C, Deshpande B, Pandey B (2013) Isolation and characterization of Rhizobium sp. from root of legume plant (Pisum sativum) and its antibacterial activity against different bacterial strains. Int Agric Food Sci 3:138-141

Boller T (2005) Peptide signalling in plant development and self/ non-self perception. Curr Opin Cell Biol 17:116-122

Bonnet E, Van de Peer Y, Rouzé P (2006) The small RNA world of plants. New Phytol 171:451-468

Bourassa DV, Kannenberg EL, Sherrier DJ, Buhr RJ, Carlson RW (2017) The lipopolysaccharide lipid A long-chain fatty acid is important for Rhizobium leguminosarum growth and stress adaptation in free-living and nodule environments. Mol Plant Microbe Interact 30:161-175

Bourcy M, Brocard L, Pislariu CI, Cosson V, Mergaert P, Tadege M, Mysore K, Udvardi M, Gourion B, Ratet P (2013) Medicago truncatula DNF2 is a PI-PLC-XD-containing protein required for bacteroid persistence and prevention of nodule early senescence and defense-like reactions. New Phytol 197(4):1250-1261

Brown DB, Huang YC, Kannenberg EL, Sherrier DJ, Carlson RW (2011) An acpXL mutant of Rhizobium leguminosarum bv. phaseoli lacks 27-hydroxyoctacosanoic acid in its lipid A and is developmentally delayed during symbiotic infection of the determinate nodulating host plant Phaseolus vulgaris. J Bacteriol 193:4766-4778

Bulgarelli D, Schlaeppi K, Spaepen S, van Themaat EVL, Schulze-Lefert P (2013) Structure and functions of the bacterial microbiota of plants. Annu Rev Plant Biol 64:807-838

Cameron DD, Neal AL, van Wees SC, Ton J (2013) Mycorrhizainduced resistance: more than the sum of its parts? Trends Plant Sci 18:539-545

Cao Y, Halane MK, Gassmann W, Stacey G (2017) The role of plant innate immunity in the legume-rhizobium symbiosis. Annu Rev Plant Biol 68:535-561

Chakraborty U, Chakraborty BN (1989) Interaction of Rhizobium leguminosarum and Fusarium solani f. sp. pisi on pea 
affecting disease development and phytoalexin production. Can J Bot 67:1698-1701

Choudhary DK, Johri BN (2009) Interactions of Bacillus spp. and plants-with special reference to induced systemic resistance (ISR). Microbiol Res 164:493-513

Clúa J, Roda C, Zanetti M, Blanco F (2018) Compatibility between legumes and rhizobia for the establishment of a successful nitrogen-fixing symbiosis. Genes 9:1-21

Conrath U, Beckers GJ, Flors V, García-Agustín P, Jakab G, Mauch F, Newman MA, Pieterse CM, Poinssot B, Pozo MJ, Pugin A (2006) Priming: getting ready for battle. Mol Plant Microbe Interact 19:1062-1071

Conrath U, Beckers GJ, Langenbach CJ, Jaskiewicz MR (2015) Priming for enhanced defense. Annu Rev Phytopathol 53: 97-119

D’Haeze W, Holsters M (2002) Nod factor structures, responses, and perception during initiation of nodule development. Glycobiology 12:79-105

D’Haeze W, Leoff C, Freshour G, Noel KD, Carlson RW (2007) Rhizobium etli CE3 bacteroid lipopolysaccharides are structurally similar but not identical to those produced by cultured CE3 bacteria. J Biol Chem 282:17101-17113

Das K, Prasanna R, Saxena AK (2017) Rhizobia: a potential biocontrol agent for soilborne fungal pathogens. Folia Microbiol 62:425-435

Day RB, Okada M, Ito Y, Tsukada K, Zaghouani H, Shibuya N, Stacey G (2001) Binding site for chitin oligosaccharides in the soybean plasma membrane. Plant Physiol 126:11621173

De Castro C, Molinaro A, Lanzetta R, Silipo A, Parrilli M (2008) Lipopolysaccharide structures from Agrobacterium and Rhizobium species. Carbohydr Res 343:1924-1933. https://doi.org/10.1016/j.carres.2008.01.036

De Vleesschauwer D, Höfte M (2009) Rhizobacteria-induced systemic resistance. Adv Bot Res 51:223-281

Deakin WJ, Broughton WJ (2009) Symbiotic use of pathogenic strategies: Rhizobial protein secretion systems. Nat Rev Microbiol 7:312-320

Diaz-Valle A, López-Calleja AC, Alvarez-Venegas R (2019) Enhancement of pathogen resistance in common bean plants by inoculation with Rhizobium etli. Front Plant Sci 10:1317

Domonkos A, Kovács S, Gombár A, Kiss E, Horváth B, Kováts GZ, Farkas A, Tóth MT, Ayaydin F, Bóka K, Fodor L, Ratet P, Kereszt A, Endre G, Kaló P (2017) NAD1 controls defense-like responses in Medicago truncatula symbiotic nitrogen fixing nodules following rhizobial colonization in a BacA-independent manner. Genes 387:1-21

Donlan R (2002) Biofilms: microbial life on surfaces. Emerg Infect Dis 8:881-890

Dutta S, Mishra AK, Kumar BD (2008) Induction of systemic resistance against fusarial wilt in pigeon pea through interaction of plant growth promoting rhizobacteria and rhizobia. Soil Biol Biochem 40:452-461

Felix G, Duran JD, Volko S, Boller T (1999) Plants have a sensitive perception system for the most conserved domain of bacterial flagellin. Plant J 18(3):265-276

Ferguson BJ, Mens C, Hastwell AH, Zhang M, Su H, Jones CH, Chu X, Gresshoff PM (2019) Legume nodulation: the host controls the party. Plant Cell Environ 42(1):41-51

Fernandez-Göbel TF, Deanna R, Muñoz NB, Robert G, Asurmendi S, Lascano R (2019) Redox systemic signaling and induced tolerance responses during soybeanBradyrhizobium japonicum interaction: involvement of nod factor receptor and autoregulation of nodulation. Front Plant Sci 10:1-15

Figueredo MS, Tonelli ML, Taurian T, Angelini J, Ibañez F, Valetti L, Muñoz V, Anzuay MS, Ludueña L, Fabra A (2014) Interrelationships between Bacillus sp. CHEP5 and Bradyrhizobium sp. SEMIA6144 in the induced systemic resistance against Sclerotium rolfsii and symbiosis on peanut plants. J Biosci 39:877-885

Figueredo MS, Tonelli ML, Ibáñez F, Morla F, Cerioni G, Tordable M, Fabra A (2017) Induced systemic resistance and symbiotic performance of peanut plants challenged with fungal pathogens and co-inoculated with the biocontrol agent Bacillus sp. CHEP5 and Bradyrhizobium sp. SEMIA6144. Microbiol Res 197:65-73

Figueredo MS, Ibáñez F, Rodríguez J, Fabra A (2018) Simultaneous inoculation with beneficial and pathogenic microorganisms modifies peanut plant responses triggered by each microorganism. Plant Soil 433(1-2):353-361

Fraysse N, Lindner B, Kaczynski Z, Sharypova L, Holst O, Niehaus K, Poinsot V (2005) Sinorhizobium meliloti strain 1021 produces a low-molecular-mass capsular polysaccharide that is a homopolymer of 3-deoxy-D-manno-oct-2ulosonic acid harboring a phospholipid anchor. Glycobiology 15:101-108

Gopalakrishnan S, Sathya A, Vijayabharathi R, Varshney RK, Gowda CL, Krishnamurthy L (2015) Plant growth promoting rhizobia: challenges and opportunities. Biotech 5:355-377

Gully D, Czernic P, Cruveiller S, Mahé F, Longin C, Vallenet D, François P, Nidelet S, Rialle S, Giraud E, DasGupta M, Cartieaux F, Arrighi JF (2018) Transcriptome profiles of nod factor-independent symbiosis in the tropical legume Aeschynomene evenia. Sci Rep 8(1):10934

Gupta R, Yadav SS, Verma SK, Dubey SK (2018) Siderophore production and biocontrol potential of rhizobium isolated from non-traditional leguminous crop in MP. Int J Pure Appl Biosci 6:142-145

Gutjahr C, Paszkowski U (2009) Weights in the balance: jasmonic acid and salicylic acid signaling in root-biotroph interactions. Mol Plant-Microbe Interact 22:763-772

Haeze WD, Glushka J, Rycke RD, Holsters M, Carlson RW (2004) Structural characterization of extracellular polysaccharides of Azorhizobium caulinodans and importance for nodule initiation on Sesbania rostrata. Mol Microbiol 52: $485-500$

Iavicoli A, Boutet E, Buchala A, Métraux JP (2003) Induced systemic resistance in Arabidopsis thaliana in response to root inoculation with Pseudomonas fluorescens CHA0. Mol Plant-Microbe Interact 16:851-858

Janczarek M, Rachwał K, Marzec A, Grządziel J, PalusińskaSzysz M (2015) Signal molecules and cell-surface components involved in early stages of the legume-rhizobium interactions. Appl Soil Ecol 85:94-113

Jones JDG, Dangl JL (2006) The plant immune system. Nat Rev 444:323-329

Jones KM, Sharopova N, Lohar DP, Zhang JQ, VandenBosch KA, Walker GC (2008) Differential response of the plant Medicago truncatula to its symbiont Sinorhizobium meliloti or an exopolysaccharide-deficient mutant. Proc Natl Acad Sci 105(2):704-709 
Kalantari S, Marefat A, Naseri B, Hemmati R (2018) Improvement of bean yield and Fusarium root rot biocontrol using mixtures of Bacillus, Pseudomonas and Rhizobium. Trop Plant Pathol 43:499-505

Kannenberg EL, Carlson RW (2001) Lipid A and O-chain modifications cause Rhizobium lipopolysaccharides to become hydrophobic during bacteroid development. Mol Microbiol 39:379-392

Kannenberg EL, Reuhs BL, Forsberg LS, Carlson RW (1998) Lipopolysaccharides and K-antigens: their structures, biosynthesis, and functions. In: Spaink HP, Kondorosi A, Honykaas PJJ (eds) The Rhizobiaceae. Kluwer Publishers, pp 119-154

Karmakar K, Kundu A, Rizvi AZ, Dubois E, Severac D, Czernic P, Cartieaux F, DasGupta M (2019) Transcriptomic analysis with the progress of symbiosis in 'crack-entry'legume Arachis hypogaea highlights its contrast with 'infection thread'adapted legumes. Mol Plant-Microbe Interact 32: 271-285

Katiyar-Agarwal S, Jin H (2010) Role of small RNAs in hostmicrobe interactions. Annu Rev Phytopathol 48:225-246

Kawaharada Y, Kelly S, Nielsen MW, Hjuler CT, Gysel K, Muszyński A, Carlson RW, Thygesen MB, Sandal N, Asmussen MH, Vinther M (2015) Receptor-mediated exopolysaccharide perception controls bacterial infection. Nature 523:308-312

Kelly S, Mun T, Stougaard J, Ben C, Andersen SU (2018) Distinct Lotus japonicus transcriptomic responses to a spectrum of bacteria ranging from symbiotic to pathogenic. Front Plant Sci 9(1218): 1218

Kloepper JW, Ryu CM, Zhang S (2004) Induced systemic resistance and promotion of plant growth by Bacillus spp. Phytopathol 94:1259-1266

Kouchi H, Shimomura K, Hata S, Hirota A, Wu GJ, Kumagai H, Tajima S, Suganuma N, Suzuki A, Aoki T, Hayashi M (2004) Large-scale analysis of gene expression profiles during early stages of root nodule formation in a model legume, Lotus japonicus. DNA Res 11:263-274

Lagunas B, Schäfer P, Gifford ML (2015) Housing helpful invaders: the evolutionary and molecular architecture underlying plant root-mutualist microbe interactions. J Exp Bot 66: 2177-2186

Le Quere AJ, Deakin WJ, Schmeisser C, Carlson RW, Streit WR, Broughton WJ, Forsberg S (2006) Structural characterization of a K-antigen capsular polysaccharide essential for normal symbiotic infection in Rhizobium sp. NGR234: deletion of the rkpMNO locus prevents synthesis of 5,7-diacetamido-3, 5,7,9-tetradeoxy-non-2-ulosonic acid. J Biol Chem 281: 28981-28992

Lepek VC, D'Antuono AL (2005) Bacterial surface polysaccharides and their role in the rhizobia-legume association. Lotus Newslett 35:93-105

Liang Y, Cao Y, Tanaka K, Thibivilliers S, Wan J, Choi J, Kang Ch, Qiu J, Stacey G (2013) Nonlegumes respond to rhizobial Nod factors by suppressing the innate immune response. Science 341:1384-1387

Libault M, Farmer A, Joshi T, Takahashi K, Langley RJ, Franklin LD, He J, Xu D, May G, Stacey G (2010) An integrated transcriptome atlas of the crop model Glycine max, and its use in comparative analyses in plants. Plant J 63:86-99

Liu L, Chen X (2018) Intercellular and systemic trafficking of RNAs in plants. Nat Plants 4(11):869-878
Lohar DP, Bird DM (2003) Lotus japonicus: a new model to study root-parasitic nematodes. Plant Cell Physiol 44:1176-1184

Lohar DP, Sharopova N, Endre G, Penuela S, Samac D, Town C, Silverstein KA, VandenBosch KA (2006) Transcript analysis of early nodulation events in Medicago truncatula. Plant Physiol 140:221-234

Lopez-Gomez M, Sandal N, Stougaard J, Boller T (2011) Interplay of flg22-induced defence responses and nodulation in Lotus japonicus. J Exp Bot 63:393-401

Mabrouk Y, Zourgui L, Sifi B, Delavault P, Simier P, Belhadj O (2007) Some compatible Rhizobium leguminosarum strains in peas decrease infections when parasitised by Orobanche crenata. Weed Res 47:44-53

Martinez-Abarca F, Herrera-Cervera JA, Bueno P, Sanjuan J, Bisseling T, Olivares J (1998) Involvement of salicylic acid in the establishment of the Rhizobium meliloti-alfalfa symbiosis. Mol Plant-Microbe Interact 11:153-155

Martinez-Medina A, Flors V, Heil M, Mauch-Mani B, Pieterse CM, Pozo MJ, Ton J, van Dam NM, Conrath U (2016) Recognizing plant defense priming. Trends Plant Sci 21: 818-822

Mauch-Mani B, Baccelli I, Luna E, Flors V (2017) Defense priming: an adaptative part of induced resistance. Annu Rev Plant Biol 68:485-512

Miri M, Janakirama P, Huebert T, Ross L, McDowell T, Orosz K, Markmann K, Szczyglowski K (2019) Inside out: root cortex-localized LHK1 cytokinin receptor limits epidermal infection of Lotus japonicus roots by Mesorhizobium loti. New Phytol 222(3):1523-1537

Mishra RP, Singh RK, Jaiswal HK, Kumar V, Maurya S (2006) Rhizobium-mediated induction of phenolics and plant growth promotion in rice (Oryza sativa L.). Curr Microbiol 52:383389

Muñoz V, Ibañez F, Tordable M, Megias M, Fabra A (2015) Role of reactive oxygen species generation and Nod factors during the early symbiotic interaction between bradyrhizobia and peanut, a legume infected by crack entry. J Appl Microbiol 118:182-192

Nguyen HP, Ratu ST, Yasuda M, Göttfert M, Okazaki S (2018) InnB, a novel type III effector of Bradyrhizobium elkanii USDA61, controls symbiosis with Vigna species. Front Microbiol 9:1-10

Okazaki S, Kaneko T, Sato S, Saeki K (2013) Hijacking of leguminous nodulation signaling by the rhizobial type III secretion system. Proc Natl Acad Sci 110:17131-17136

Okazaki S, Tittabutr P, Teulet A, Thouin J, Fardoux J, Chaintreuil C, Gully D, Arrighi JF, Furuta N, Miwa H, Yasuda M, Nouwen N, Teaumroong N, Giraud E (2016) Rhizobiumlegume symbiosis in the absence of Nod factors: two possible scenarios with or without the T3SS. ISME J 10:64-74

Oldroyd GE (2013) Speak, friend, and enter: signalling systems that promote beneficial symbiotic associations in plants. Nat Rev Microbiol 11:252-263

Ongena M, Jourdan E, Adam A, Paquot M, Brans A, Joris B, Arpigny JL, Thonart P (2007) Surfactin and fengycin lipopeptides of Bacillus subtilis as elicitors of induced systemic resistance in plants. Environ Microbiol 9:1084-1090

Osdaghi E, Shams-Bakhsh M, Alizadeh A, Lak MR, Maleki HH (2011) Induction of resistance in common bean by Rhizobium leguminosarum bv. phaseoli and decrease of common bacterial blight. Phytopathol Mediterr 50:45-54 
Pellock BJ, Cheng HP, Walker GC (2000) Alfalfa root nodule invasion efficiency is dependent on Sinorhizobium meliloti polysaccharides. J Bacteriol 182:4310-4318

Pieterse CMJ, Van der Does D, Zamioudis C, Leon-Reyes A, Van Wees SCM (2012) Hormonal modulation of plant immunity. Annu Rev Cell Dev Biol 28:489-521

Pieterse CMJ, Zamioudis C, Berendsen RL, Weller DM, Van Wees SC, Bakker PA (2014) Induced systemic resistance by beneficial microbes. Annu Rev Phytopathol 52:347-375

Rabie GH (1998) Induction of fungal disease resistance in Vicia faba by dual inoculation with Rhizobium leguminosarum and vesicular-arbuscular mycorrhizal fungi. Mycopathol 141: $159-166$

Ramadas Bhat U, Forsberg LS, Carlson RW (1994) Structure of lipid a component of Rhizobium leguminosarum bv. phaseoli lipopolysaccharide. Unique nonphosphorylated lipid A containing 2-amino-2-deoxygluconate, galacturonate, and glucosamine. J Biol Chem 269: 14402-14410

Reitz M, Rudolph K, Schröder I, Hoffmann-Hergarten S, Hallmann J, Sikora RA (2000) Lipopolysaccharides of Rhizobium etli strain G12 act in potato roots as an inducing agent of systemic resistance to infection by the cyst nematode Globodera pallida. Appl Environ Microbiol 66:3515-3518

Reuhs BL, Carlson RW, Kim JS (1993) Rhizobium fredii and Rhizobium meliloti produce 3-deoxy-D-manno-2octulosonicacid-containing polysaccharides that are structurally analogous to group II K antigens (capsular polysaccharides) found in Escherichia coli. J Bacteriol 175:3570-3580

Reuhs BL, Williams MN, Kim JS, Carlson RW, Cote F (1995) Suppression of the fix phenotype of Rhizobium meliloti exoB mutants by lps $Z$ is correlated to a modified expression of the K polysaccharide. J Bacteriol 177:4289-4296

Rey T, Nars A, Bonhomme M, Bottin A, Huguet S, Balzergue S, Jacquet C (2013) NFP, a LysM protein controlling Nod factor perception, also intervenes in Medicago truncatula resistance to pathogens. New Phytol 198:875-886

Rey T, André O, Nars A, Dumas B, Gough C, Bottin A, Jacquet C (2019) Lipo-chitooligosaccharide signalling blocks a rapid pathogen-induced ROS burst without impeding immunity. New Phytol 221(2):743-749

Saijo Y, Po-iian Loo E, Yasuda S (2018) Pattern recognition receptors and signaling in plant-microbe interactions. Plant J 93:592-613

Scheidle H, Gross A, Niehaus K (2005) The lipid A substructure of the Sinorhizobium meliloti lipopolysaccharides is sufficient to suppress the oxidative burst in host plants. New Phytol 165:559-565

Schmidt TM, Thomé AHE, Sperotto RA, Granada CE (2018) Effect of rhizobia inoculation on the development of soilborne pathogens infecting common bean plants. Eur J Plant Pathol 153:687-694

Schue M, Fekete A, Ortet P, Brutesco C, Heulin T, SchmittKopplin P, Achouak W, Santaella C (2011) Modulation of metabolism and switching to biofilm prevail over exopolysaccharide production in the response of Rhizobium alamii to cadmium. PLoS One 6:11

Sinharoy S, Torres-Jerez I, Bandyopadhyay K, Kereszt A, Pislariu CI, Nakashima J, Benedito VA, Kondorosi E, Udvardi MK (2013) The C $2 \mathrm{H} 2$ transcription factor regulator of symbiosome differentiation represses transcription of the secretory pathway gene VAMP721 $a$ and promotes symbiosome development in Medicago truncatula. Plant Cell 25:3584 3601

Smigielski L, Laubach EM, Pesch L, Glock JML, Albrecht F, Slusarenko AJ, Panstruga R, Kuhn H (2019) Nodulation induces systemic resistance of Medicago truncatula and Pisum sativum against Erysiphe pisi and primes for powdery mildew-triggered salicylic acid accumulation. Mol Plant Microbe Interact 32:1243-1255

Songwattana P, Noisangiam R, Teamtisong K, Prakamhang J, Teulet A, Tittabutr P, Piromyou P, Boonkerd N, Giraud E, Teaumroong N (2017) Type 3 secretion system (T3SS) of Bradyrhizobium sp. DOA9 and its roles in legume symbiosis and rice endophytic association. Front Microbiol 8:1810

Soto MJ, Sanjuán J, Olivares J (2006) Rhizobia and plantpathogenic bacteria: common infection weapons. Microbiol 152:3167-3174

Soto MJ, Domínguez-Ferreras A, Pérez-Mendoza D, Sanjuán J, Olivares J (2009) Mutualism versus pathogenesis: the giveand-take in plant-bacteria interactions. Cell Microbiol 11: 381-388

Srinivasan T (2017) Studies on antifungal activity of siderophores produced by rhizobium spp isolated from groundnut (Arachis hypogaea). J Agric Sci Food Res 8:1-27

Stringlis IA, Proietti S, Hickman R, Van Verk MC, Zamioudis C, Pieterse CMJ (2018) Root transcriptional dynamics induced by beneficial rhizobacteria and microbial immune elicitors reveal signatures of adaptation to mutualists. Plant J 93:166180

Tazawa J, Takahashi M, Usuki K, Yamamoto H (2007) Nodulation during vegetative growth of soybean stage does not affect the susceptibility to red crown rot caused by Calonectria ilicicola. J Gen Plant Pathol 73:180-184

Tellström V, Usadel B, Thimm O, Stitt M, Küster H, Niehaus K (2007) The lipopolysaccharide of Sinorhizobium meliloti suppresses defense-associated gene expression in cell cultures of the host plant Medicago truncatula. Plant Physiol 143:825-837

Tonelli ML, Furlan A, Taurian T, Castro S, Fabra A (2011) Peanut priming induced by biocontrol agents. Physiol Mol Plant $\mathrm{P}$ 75:100-105

Tsikou D, Yan Z, Holt DB, Abel NB, Reid DE, Madsen LH, Bhasin H, Sexauer M, Stougaard J, Markmann K (2018) Systemic control of legume susceptibility to rhizobial infection by a mobile microRNA. Science 362:233-236

Van Loon LC, Bakker PHM, Pieterse JCM (1998) Systemic resistance induced by rhizosphere bacteria. Annu Rev Phytopathol 36:453-483

Van Wees SC, Van der Ent S, Pieterse CMJ (2008) Plant immune responses triggered by beneficial microbes. Curr Opin Plant Biol 11:443-448

Volpiano CG, Lisboa BB, São José JFB, de Oliveira AMR, Beneduzi A, Passaglia LMP, Vargas LK (2018) Rhizobium strains in the biological control of the phytopathogenic fungi Sclerotium (Athelia) rolfsii on the common bean. Plant Soil 432:229-243

Volpiano CG, Lisboa BB, Granada E, São José JBF, de Oliveira AMR, Beneduzi A, Perevalova Y, Passaglia LMP, Vargas LK (2019) Rhizobia for biological control of plant diseases. In: Kumar V, Prasad R, Kumar M, Choudhary D (eds) 
Microbiome in plant health and disease. Springer, Singapore, pp 315-336

Yamaya-Ito H, Shimoda Y, Tsuneo H, Shusei S, Takakazu K, Shakhawat H, Satoshi S, Masayoshi K, Makoto H, Hiroshi K, Yosuke (2018) Loss-of-function of ASPARTIC PEPTIDASE NODULE-INDUCED 1 (APN1) in Lotus japonicus restricts efficient nitrogen-fixing symbiosis with specific Mesorhizobium loti strains. Plant J 93:5-16

Yang S, Tang F, Gao M, Krishnan HB, Zhu H (2010) $R$ genecontrolled host specificity in the legume rhizobia symbiosis. PNAS 107:18735-18740
Yu K, Pieterse CMJ, Bakker PA, Berendsen RL (2019) Beneficial microbes going underground of root immunity. Plant Cell Environ 2019:1-11

Zamioudis C, Pieterse CMJ (2012) Modulation of host immunity by beneficial microbes. Mol Plant Microbe Interact 25:139150

Publisher's note Springer Nature remains neutral with regard to jurisdictional claims in published maps and institutional affiliations. 